\title{
Morphological and physiological studies in three alfalfa varieties (Medicago sativa L.) under salt stress
}

\author{
Majid Mezni ${ }^{1}$, Sywar Haffani ${ }^{2}$, Ali Albouchi ${ }^{3}$ \\ ${ }^{1,2}$ Université de Carthage. Laboratoire des Productions Animales et Fourragères. INRAT, Rue Hédi Karray \\ 2049, Ariana, Tunisie. \\ ${ }^{3}$ Unité d'Agro-Sylvo-Pastoralisme. INRGREF, BP 10, 2080 Ariana, Tunisie.
}

\begin{abstract}
Responses to salt stress were investigated in three alfalfa varieties (Gabès, Hunterfield, and Hyb.555). Seedlings were submitted to salinity induced by adding $\mathrm{NaCl}$ into water at 4 concentrations $(0-2.5$ 5 and $\left.10 \mathrm{~g} . l^{-1}\right)$. Growth parameters (DM, plant height, LA, LAR, SLA, leaves thickness, succulence), and hydraulic parameters ( $R W C, W C, W U E)$ were investigated in leaves, stems and roots after three months of salt stress. Results showed that $\mathrm{NaCl}$ decreased DMY of the three varieties. However, Gabès variety, compared to Hunterfield and Hyb.555 has a DMY significantly higher, in the absence and presence of $\mathrm{NaCl}$. The severe decrease in the DMY of the introduced varieties was related to the premature senescence accelerated by the salt intensity and the duration. On the other hand, Gabès variety has a well-equilibrated distribution of DM between organs. The LAR and the SLA decreased significantly with the salt increasing. The salt increased the leaves thickness and succulence. WC increased in concomitance with the rise of leaf succulence. WUE under salt stress decreased in the three lucernes. However, Gabès variety has WUE significantly higher in all salt treatments. This study allowed highlighting the interest of the Gabès variety in any selection program for salt tolerance.

Key words: Alfalfa, Growth parameters, hydraulic parameters, Salinity.
\end{abstract}

\section{Introduction}

Among abiotic stress, the salinity is one of the most constraints environmental which provokes grave threats for the agriculture and the environment (Lugan, 2008; Shahid et al., 2011). Salted soils and waters constitute an unfavorable environment for the increase of the agronomic yields (Hammad and al., on 2010). Indeed, the salinisation of the soil is a major obstacle to the productivity of the main cultivated species. Tunisia possessed vast salty zones (Chott and Sebkha) and an important water resource with a salinity varying between 1.5 to $3 \mathrm{~g} . \mathrm{l}^{-1}$ (Al Atiri, 2004; Ben Nouna et al., 2004). According to Hachicha (2007), soils affected by salts in Tunisia covered approximately 1.5 million hectares, which represented about $10 \%$ of the country surface.

The salty soils are generally situated in the dry and the Saharan area, and then they are subjected to an intense evaporation which favored the rise of salts on-surface (Lapeyronie, 1982; Marlet et al., 2008) and provoked the mortality of plants, resulting to the decrease of the soil osmotic potential (Da Silva et al., 2008). The strong concentrations of salts in the soil decreased the water extraction by roots (Munns and Tester, 2008). Confronted to salinity, plants developed several adaptation strategies such as: compartmentation (Li et al., 2008; Smethurst et al., 2009; Sun et al., 2009; Hanana et al., 2011) and/or $\mathrm{Na}^{+}$and $\mathrm{Cl}^{-}$dilution by dry matter production (Hamrouni et al., 2011; Ibn Maaouia-Houimli et al., 2011), leaves succulence (Lacerda et al., 2006; Hameed et al., 2010; Fercha et al., 2011), leaves thickness (Suárez, 2011; Boughalleb et al., 2012), ions exclusion to the stem parenchyma (Munns and James, 2003; Suárez and Medina, 2008; Mezni et al., 2010).

In Tunisia, the livestock sector constituted in value $36 \%$ of the total agricultural production, with more than 600 thousand jobs and 1 million of direct and indirect workdays a year. The area reserved to the rainfed forage crops produced, according to the level of rain, between 460 and 750 million of fodder units (30\% of the average cover rate), compared for needs esteemed to 1400 million UF (Dahi, on 2008). This chronic deficit needed a big effort to improve the productivity of the existing forage crops. This was the Tunisia challenge to maintain the agricultural productivity in these zones affected by the salinity by the use of tolerant alfalfa genotypes (Singh et al., 2010; Javid et al., on 2011).

The objective of the study was to investigate the effect of salt stress on the growth and the water balance in three alfalfa varieties, to integrate them into selection programs, in order to create tolerant genotypes for the salinity, to value and develop the Tunisian salty soils and the brackish waters.

\section{Materials And Methods}

Plant material and growth conditions

Plants were cultivated in greenhouse (natural light; maximal temperatures of 30 to $42^{\circ} \mathrm{C}$ and minimal of 15 to $28^{\circ} \mathrm{C}$; maximal relative humidity of 80 to $95 \%$ and minimal of 25 to $45 \%$ ). The seedling was carried out in plastic pots (volume $=10$ litres) containing an equilibrated soil with a basic $\mathrm{pH}(8.2)$, rich in active chalk $(13 \%)$. 
It has a humidity fluctuating between: $12.1 \%$ at wilting point and $22.6 \%$ at field capacity. Pots were daily irrigated and continuously drained and drainage water was collected in small bottles. The quantities of water necessary for each irrigation treatment were determined using mini-lysimeters. The soil was maintained at the field capacity throughout the experiment.

Each pot contained ten plants of the same variety. Before achieving this density, an initial sowing of twenty seeds per pot was carried out, followed by a thinning at the four leaves trifoliate stage to leave only the ten best plants, while respecting an uniform spatial distribution between individuals. Seedlings were first irrigated with tap water during establishment (20 days). Two water samples were taken monthly to monitor their chemical composition. The average concentration was: $0.2 \mathrm{meq} \cdot \mathrm{l}^{-1}$ for $\mathrm{K}^{+}, 12$ to $17 \mathrm{meq} \cdot \mathrm{l}^{-1}$ for $\mathrm{Ca}^{2+}, 2$ to $5 \mathrm{meq} . \mathrm{l}^{-1}$ for $\mathrm{Na}^{+}$, and 2 to 6 meq. $\mathrm{l}^{-1}$ for $\mathrm{Cl}^{-}$.

At the four leaves trifoliate stage, salinity stress was induced by adding $\mathrm{NaCl}$ into water irrigation at 4 concentrations $\left(0-2.5-5\right.$ and $\left.10 \mathrm{~g} . \mathrm{l}^{-1}\right)$. The experimental design included 12 treatments $(3$ varieties $\mathrm{x} 4$ levels of salinity), with randomized 4 replications, resulting in a total of 48 pots and 480 plants.

To avoid osmotic shocks, the salt was supplied with irrigation water using increasing gradual fractions until the desired level of each treatment is reached. It took 12 days to fully establish the saline treatments. Thereafter, weekly analyze were done either on soil or on excess drainage water to insure that $\mathrm{NaCl}$ concentration in medium was constant. This procedure allowed us to monitor $\mathrm{NaCl}$ quantities taken up by alfalfa plants or adsorbed by the exchangeable complex in the soil.

\section{Growth parameters}

The growth parameters were carried out on plants harvested at the late bloom-early pod stage, corresponding to a salt stress period of three months. The leaf area (LA) was calculated by the method of weighting, on leaves completely developed. Leaves are quickly photocopied and their imprints carefully cut and weighed. The LA was then deducted, with the weight of a known surface area. The LA per plant was obtained by multiplying the LA average by the corresponding leaves number (Mezni et al., 1999).

The leaf area ratio (LAR) was calculated as the ratio of total leaf area on the whole plant dry matter (DM) and it was expressed in $\mathrm{cm}^{2}$ of leaves by $\mathrm{mg}$ of DM $\left(\mathrm{cm}^{2} \cdot \mathrm{mg}^{-1} \mathrm{DM}\right)$. The specific leaf area (SLA) designed the ratio of leaf area to leaf dry mass and expressed in $\mathrm{cm}^{2} \cdot \mathrm{mg}^{-1}$ leaves DM (Garnier et al., 2001). Leaves thickness was calculated as water content of leaves (Volume) by specific leaf area.

\section{Water parameters}

Water parameters were measured in the morning from 10 hours, on completely developed leaves. Relative water content (RWC) was measured in eight fully expanded leaves without petiole per treatment. Leaves were immediately weighed after the harvest, to determine their fresh weight (FW). Leaves were immersed on distilled water in Petri dishes for 4 hours (time required to regain turgidity after many essays). Then, leaves are carefully wiped with the filter paper to remove the water droplets on their surface and weighed to determine turgid weight (TW). The samples were dried at $80^{\circ} \mathrm{C}$ for 24 h to determine the dry weight (DW). RWC was defined as follows:

$$
R H C(\%)=\frac{F W \cdot D W}{T W-D W} \times 100
$$

Leaf water content (WC) was determined by weighing leaves immediately on harvest (FW) and after complete dried at $80^{\circ} \mathrm{C}$ for $24 \mathrm{~h}$ (DW) using an analytical balance. WC was given by the following formula:

$$
W C\left(g H_{2} O \cdot g^{-1} D W\right)=\frac{F W-D W}{D W}
$$

The leaves succulence by treatment was calculated on a sample of eight grown-up leaves by the following relation:

$$
\text { Succulence }\left(\mathrm{mgH}_{2} \mathrm{O} \cdot \mathrm{cm}^{2}\right)=\frac{F W-\mathrm{DW}}{\mathrm{LA}}
$$

The water use efficiency (WUE) was determined by successive weighing of the culture pots, constantly maintained in the field capacity. To estimate the losses of water by evaporation, one pot per treatment without culture was installed. For each treatment, the quantity of water consumed was then determined by the difference between the weight of the pot containing plants and without plant. 


\section{Statistical analysis}

Confidence intervals were calculated to the threshold of 95\% probability. General Linear Models of SAS was used to explain the degree of significance of each factor and of the interactions between different factors. The Duncan test was used to compare treatment means for all studied parameters.

\section{Effect of $\mathrm{NaCl}$ on the dry matter (DM)}

\section{Results}

The figure1 represented total DM of whole plant (W.P.), shoots (S) and roots (R). The salt stress affected negatively the alfalfa DM. At the most stressful treatment and compared to the control, the Gabès DM decrease was lower and the reduction did not exceeded 37\%, whereas the decline was $45 \%$ and $59 \%$ for Hyb.555 and Hunterfield respectively, at the same treatment. Indeed, the shoots of the introduced varieties was more marked by the salt intensity than the roots biomass, the reduction was $68 \%$ and $59 \%$ respectively.

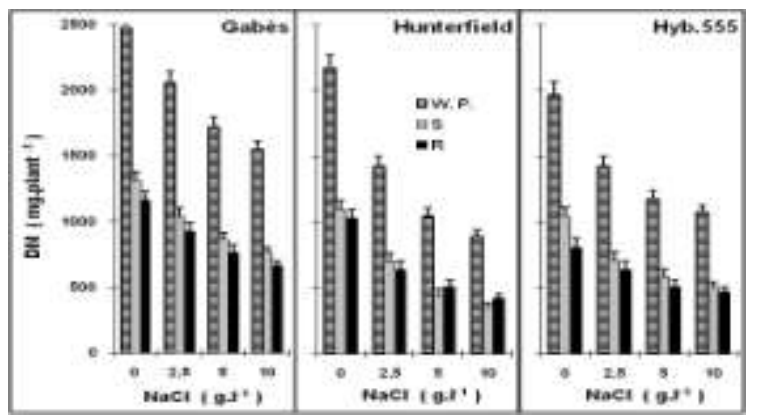

Figure 1. DM of whole plant (W.P.), Shots (S) and Roots (R) of three alfalfa varieties, in presence of increasing $\mathrm{NaCl}\left(0-2.5-5-10 \mathrm{~g} . \mathrm{l}^{-1}\right)$, after three months of salt treatments. Confidence intervals were calculated at $\alpha=$ $95 \%$ probability level.

\section{Distribution of the DM between the various organs}

The distribution of the DM between roots (R), stems (S), senescent leaves (Sen. L.) and photosynthetically active leaves $(\mathrm{L})$ is represented by the figure 2 . The distribution of the DM showed that roots DM, for the three varieties, never coming down below $42 \%$ of the total biomass of the whole plant. The roots DM of Hunterfield variety, under the stressful treatment $\left(10 \mathrm{~g} .1^{-1}\right)$, represented $55 \%$ of the total biomass. While for Gabès and Hyb.555 varieties, the DM fraction of stems and leaves photosynthetically active was appreciably stable and was little modified by the increase of the salt in the culture medium. For these two varieties, the mass of every organ constituted about $25 \%$ of the whole plant DM. On the contrary, DM of stems and especially leaves photosynthetically active of Hunterfield variety was significantly reduced by the increased doses of $\mathrm{NaCl}$ in the culture pots. Indeed, the Hunterfield foliar mass, compared to whole plant DM passed for $25 \%$ under the control treatment (without salt) to $14 \%$ in the most stressful treatment $\left(10 \mathrm{~g} \cdot \mathrm{l}^{-1}\right)$.

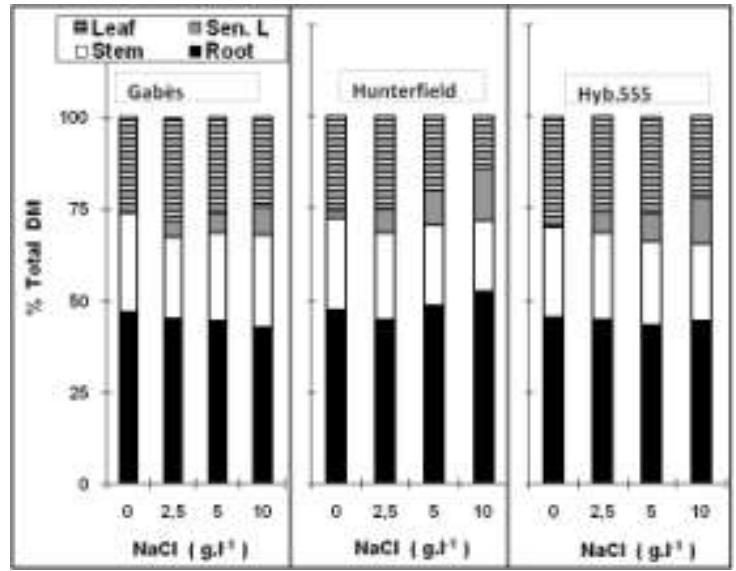

Figure 2. DM distribution between Leaves (L), Senescent Leaves (Sen. L), Stems (S) and Roots (R) of three alfalfa varieties, in presence of $\mathrm{NaCl}\left(0-2.5-5-10 \mathrm{~g} \cdot 1^{-1}\right)$, after three months of salt treatments. Confidence intervals were calculated at $\alpha=95 \%$ probability level. 


\section{Plant height}

The result recorded on the figure 3 represented the evolution of the plant height, under increasing salt intensities. The height growth for the three varieties decreased with the increase of $\mathrm{NaCl}$ in the medium. So, the Hyb.555 height was more affected by the salt, compared to the other varieties, with a height level significantly lower at the stressful treatment.

The analysis of variance of the plant height showed a highly significant effect $(p<0.0001)$ for variety, salinity and their interaction. The Duncan test ranked the varieties in the following order for the height growth: Gabès $\geq$ Hunterfield $>$ Hyb.555.

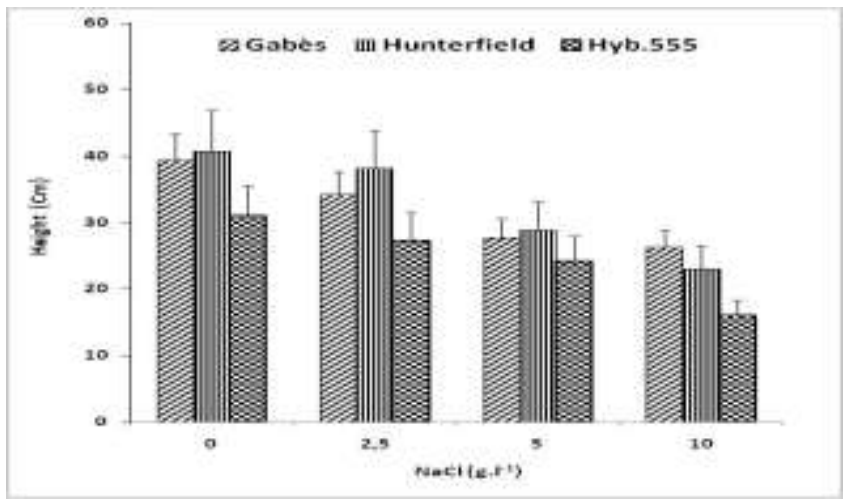

Figure 3. Height growth of the three alfalfa varieties, in presence of increasing $\mathrm{NaCl}\left(0-2.5-5-10 \mathrm{~g} . \mathrm{l}^{-1}\right)$, after three months of salt treatments. Confidence intervals were calculated at $\alpha=95 \%$ probability level.

\section{Leaf area $(L A)$}

The results showed that the salt stress decreased the LA growth (figure 4). However, the LA of Gabès variety was significantly more important at 2.5 and $5 \mathrm{~g} .1^{-1}$ treatments, compared to the two introduced varieties. For the most stressful treatment $\left(10 \mathrm{~g} .1^{-1}\right)$, the three alfalfa varieties have appreciably the same LA with a reduction of the number of leaves resulting of their premature senescent.

The analysis of variance of the LA showed a highly significant effect $(\mathrm{p}<0.0001)$ for variety, salinity and their interaction. The Duncan test ranked the varieties in the following order for the LA: Gabès > Hyb.555 > Hunterfield.

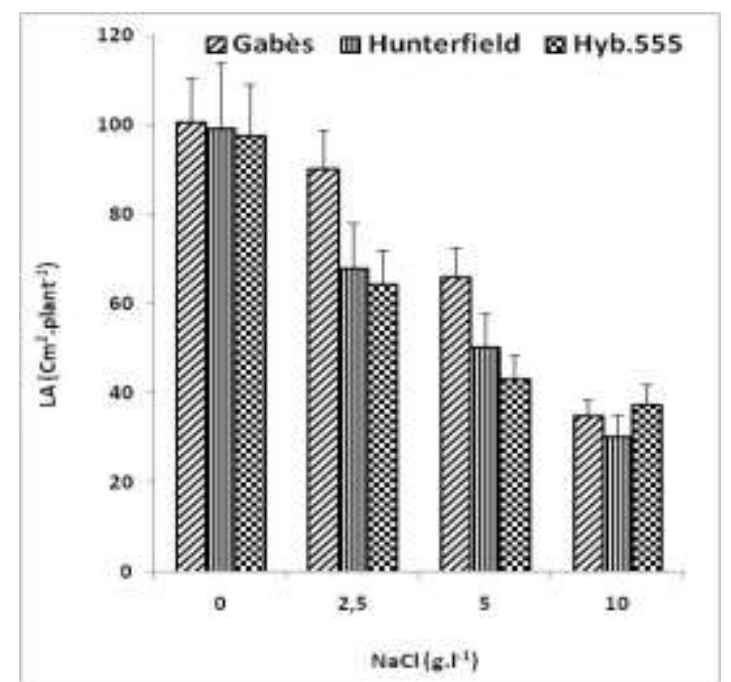

Figure 4. LA of the three alfalfa varieties, in presence of increasing $\mathrm{NaCl}\left(0-2.5-5-10 \mathrm{~g} . \mathrm{l}^{-1}\right)$, after three months of salt treatments. Confidence intervals were calculated at $\alpha=95 \%$ probability level.

\section{Leaf area ratio (LAR)}

The figure 5 described the LAR evolution of the three alfalfa varieties in absence and presence of increasing concentrations of $\mathrm{NaCl}$. The results showed that the dose of $2.5 \mathrm{~g} .1^{-1}$ increased the LAR in the three alfalfa varieties. Beyond this concentration, the LAR decreased for the three varieties with however a severe reduction for Hunterfield in the most stressful treatment $\left(10 \mathrm{~g} \cdot \mathrm{l}^{-1}\right)$. 


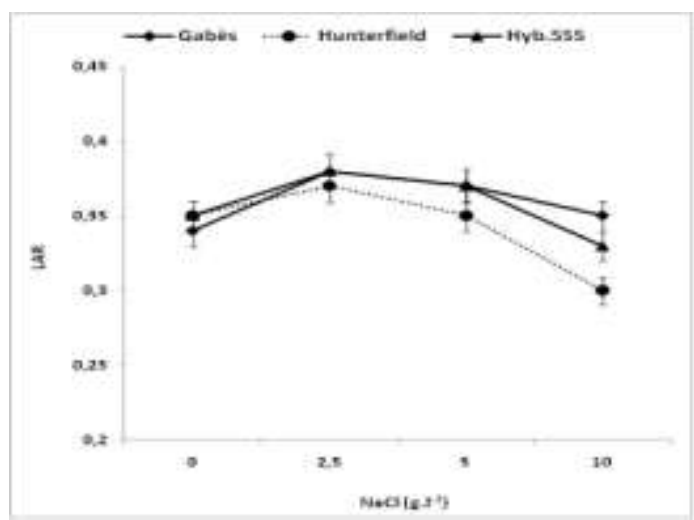

Figure 5 - The LAR of the three alfalfa varieties $\left(\mathrm{cm}^{2} . \mathrm{mg}^{-1} \mathrm{DM}\right.$ of whole plant), in presence of increasing $\mathrm{NaCl}$ $\left(0-2.5-5-10 \mathrm{~g} . \mathrm{l}^{-1}\right)$, after three months of salt treatments. Confidence intervals were calculated at $\alpha=95 \%$ probability level.

\section{Specific leaf area (SLA)}

The SLA decreased with the $\mathrm{NaCl}$ increasing in the culture medium, for the three alfalfa varieties (figure 6). In the control treatment, the three varieties had the same SLA. The SLA of the introduced Hunterfield and $H y b .555$ varieties was affected by the salt with the same intensity. The SLA decrease was more important for those varieties (52\%) compared to Gabès decrease (34\%). In 10 g. $\mathrm{l}^{-1}$ of $\mathrm{NaCl}$ treatment, the local variety Gabès has a SLA significantly higher; this was confirmed by the variance analysis which revealed a very highly significant effect ( $<0.0001)$ of "varieties", "salinity" and of their interaction.

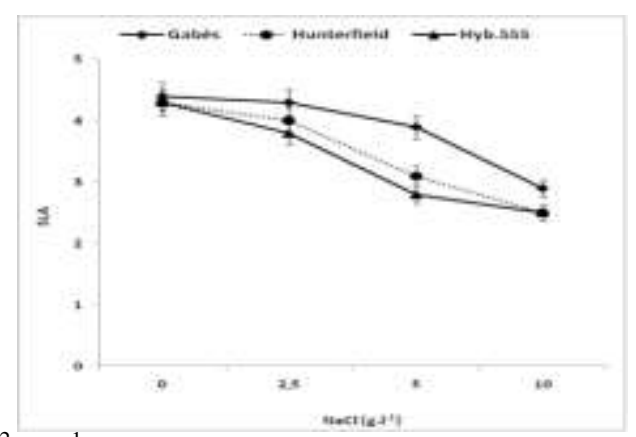

Figure 6 - Specific leaf area $\left(\mathrm{cm}^{2} \cdot \mathrm{mg}^{-1}\right.$ Leaves DM) of the three alfalfa varieties, in presence of increasing $\mathrm{NaCl}$ $\left(0-2.5-5-10 \mathrm{~g} .1^{-1}\right)$, after three months of salt treatments. Confidence intervals were calculated at $\alpha=95 \%$ probability level.

\section{Leaves thickness}

The leaves thickness was calculated by dividing the leaves water content by the corresponding foliar specific surface. The figure 7 represented the evolution of the leaves thickness of three alfalfa varieties after three months of salt stress. Results showed that the three varieties had practically the same leaves thickness in the control treatment. The thickness increased with the rise of $\mathrm{NaCl}$. However, the leaves thickness of Gabès variety, compared to the introduced varieties, augmented linearly with $\mathrm{NaCl}$ increasing and reached a level significantly higher at the most stressful treatment $\left(10 \mathrm{~g} \cdot 1^{-1}\right)$.

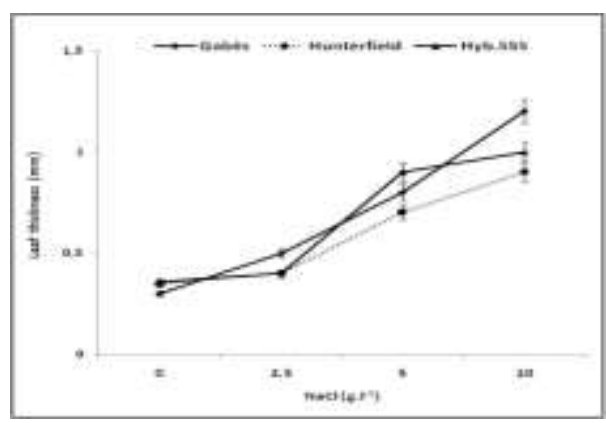

Figure 7 - Leaves thickness of the three alfalfa varieties, in presence of increasing $\mathrm{NaCl}\left(0-2.5-5-10 \mathrm{~g} \cdot 1^{-1}\right)$, after three months of salt treatments. Confidence intervals were calculated at $\alpha=95 \%$ probability level. 


\section{Leaves succulence}

Results showed that the three alfalfa varieties developed a succulence highly correlated with the increase of the salt in the medium culture $(\mathrm{r}=0.98)$. Under 2.5 and $5 \mathrm{~g} \cdot \mathrm{l}^{-1} \mathrm{NaCl}$ treatments, the leaves succulence of Gabès was significantly lower, compared to the introduced varieties (figure 8). However, after $5 \mathrm{~g} .1^{-1} \mathrm{NaCl}$ treatment, the succulence of Gabès quickly increased to reach at $10 \mathrm{~g} . \mathrm{l}^{-1}$, a level significantly higher.

The variance analysis of the leaves succulence showed a very highly significant effect $(p<0.0001)$ of "salinity" and the interaction " salinity $\mathrm{x}$ varieties " but no significant effect of varieties $(0.2254)$.

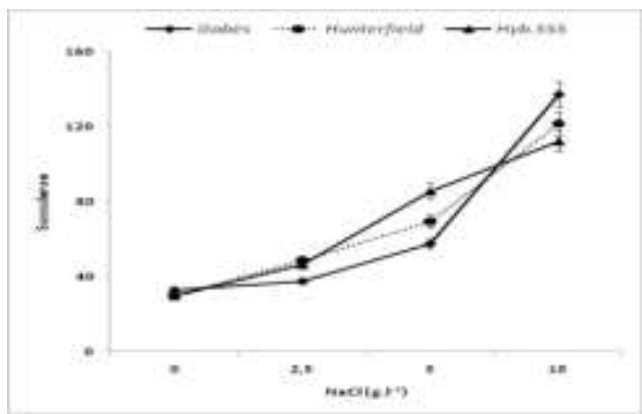

Figure 8 - Leaves succulence $\left(\mathrm{mgH}_{2} \mathrm{O} . \mathrm{cm}^{2} \mathrm{LA}\right)$ of the three alfalfa varieties, in presence of increasing $\mathrm{NaCl}(0$ $\left.2.5-5-10 \mathrm{~g} \cdot \mathrm{l}^{-1}\right)$, after three months of salt treatments. Confidence intervals were calculated at $\alpha=95 \%$ probability level.

\section{Relative water content ( $R W C$ )}

The relative water content of the introduced varieties (Hunterfield and Hyb.555) decreased appreciably with the same intensity (figure 9). On the other hand, RWC of Gabès decreased up to $2.5 \mathrm{~g} .1^{-1}$ treatment, and increased to achieve in $10 \mathrm{~g} .1^{-1}$ of $\mathrm{NaCl}$, a RWC level identical under $2.5 \mathrm{~g} .1^{-1}$ of $\mathrm{NaCl}$ treatment.

The variance analysis of the RWC, revealed a very highly significant effect ( $<0.0001)$ of "varieties", "salinity" and of their interaction. The Duncan test ranked varieties in the following order: Gabès $\geq$ Hyb.555 $\geq$ Hunterfield.

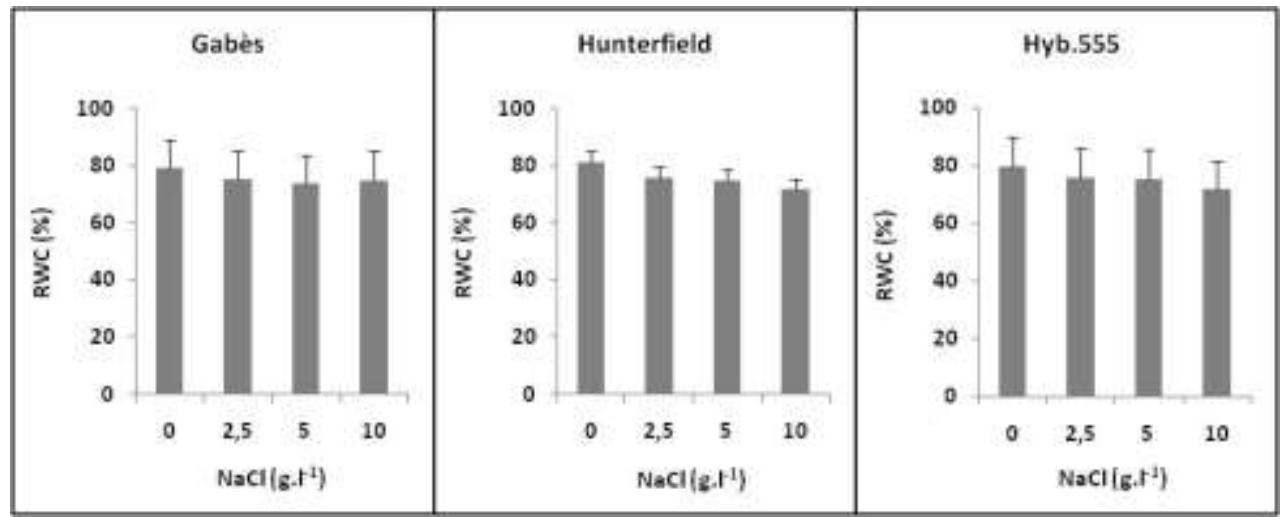

Figure $9-\mathrm{RWC}$ of the three alfalfa varieties, in presence of increasing $\mathrm{NaCl}\left(0-2.5-5-10 \mathrm{~g} . \mathrm{l}^{-1}\right)$, after three months of salt treatments. Confidence intervals were calculated at $\alpha=95 \%$ probability level.

\section{Water content $(\mathrm{WC})$}

The water content of Gabès variety under $2.5 \mathrm{~g} \cdot \mathrm{l}^{-1}$ of $\mathrm{NaCl}$ was practically the same with the control treatment. For Gabès and Hyb.555, WC increased significantly with the rise of $\mathrm{NaCl}$ in the medium environment (figure 10). Compared to the introduced varieties, the WC of Gabès variety was significantly higher at the most stressful treatment $\left(10 \mathrm{~g} . \mathrm{l}^{-1}\right)$. For Hunterfield, the WC increased very slowly with the salinity intensity.

The analysis of variance of the water content showed a very highly significant effect $(p<0.0001)$ of "varieties", "salinity" and of their interaction. The Duncan test showed the superiority of Gabès, compared to two introduced varieties. 

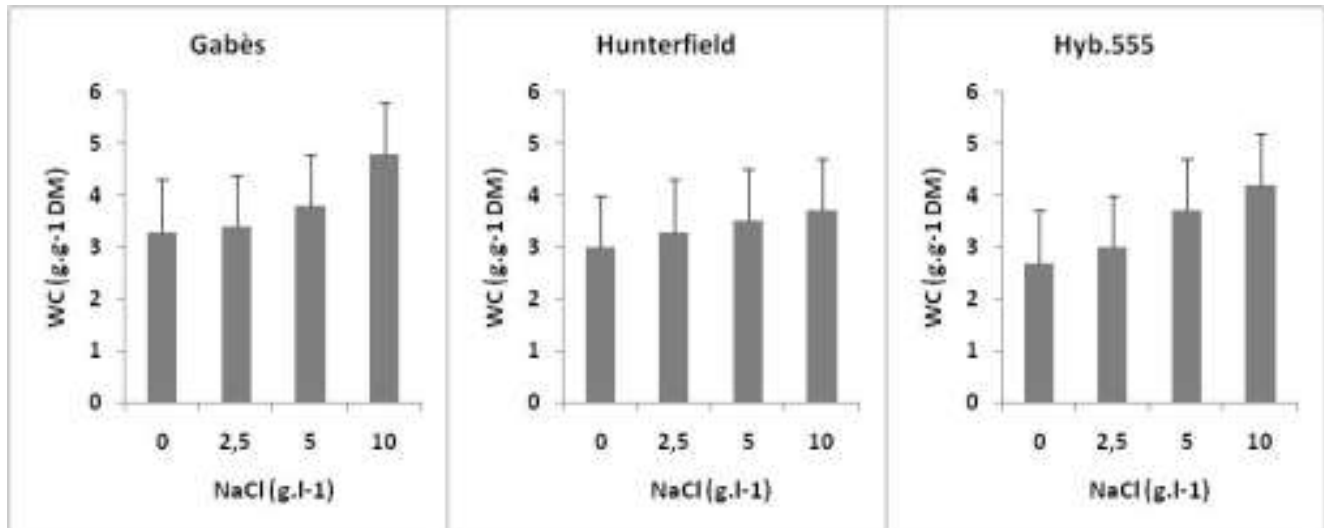

Figure 10. Water content $\left(\mathrm{H}_{2} \mathrm{O} \mathrm{g} \cdot \mathrm{g}^{-1} \mathrm{DM}\right)$ of the three alfalfa varieties, in presence of increasing $\mathrm{NaCl}(0-2.5-5$ $\left.-10 \mathrm{~g} . \mathrm{l}^{-1}\right)$, after three months of salt treatments. Confidence intervals were calculated at $\alpha=95 \%$ probability level.

\section{Water use Efficiency (WUE)}

The salt stress decreased the WUE for three alfalfa varieties (figure 11). Indeed, water requirements to produce one gram of dry matter for Gabès variety passed of $0.6 \mathrm{~kg}$ (control) to $2 \mathrm{~kg}$ under the most stressful treatment $\left(10 \mathrm{~g} .1^{-1}\right)$. While water requirements for the introduced varieties, varied between $0.7 \mathrm{~kg}$ and $3 \mathrm{~kg}$ in absence and in the presence of $10 \mathrm{~g} .1^{-1} \mathrm{NaCl}$ respectively. The decrease of the WUE was highly correlated with the increasing of doses of $\mathrm{NaCl}$ in the medium. The coefficients of determination for the three varieties are very high $\left(\mathrm{R}^{2}=0.99\right)$.

The Gabès variety was distinct from the two introduced varieties, by a better WUE, for all the salt treatments and especially for the most stressful treatments. The Hunterfield and Hyb.555 varieties had appreciably the same WUE. This similarity was translated by a bad valuation of the water absorbed by the plant to produce DM.

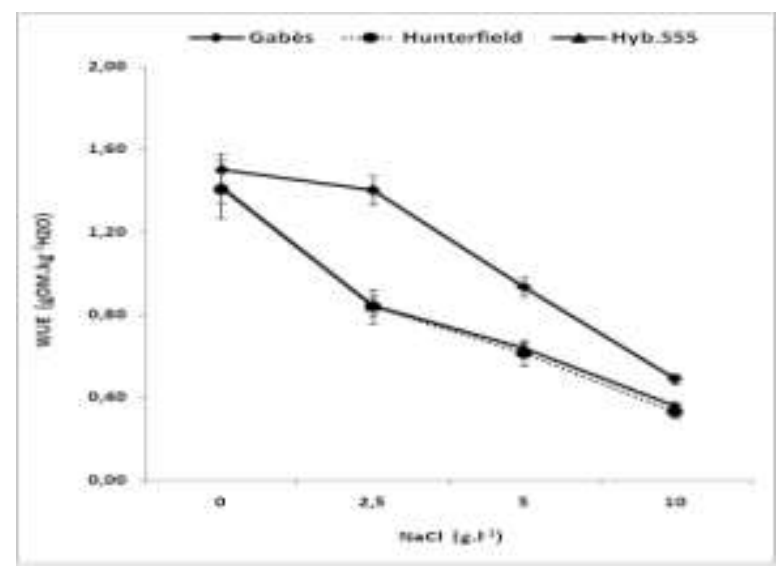

Figure 11. WUE of the three alfalfa varieties, in presence of increasing $\mathrm{NaCl}\left(0-2.5-5-10 \mathrm{~g} . \mathrm{l}^{-1}\right)$, after three months of salt treatments. Confidence intervals were calculated at $\alpha=95 \%$ probability level.

\section{Discussion}

The objective of this investigation is to study the physiological responses of three alfalfa varieties (Medicago sativa L.) to salt stress for salt tolerance screening. The alfalfa tolerance was estimated by the biomass production under salt stress. Indeed, the effects of $\mathrm{NaCl}$ on the growth, showed a decrease in dry matter yield (DMY) of the three Lucerne varieties. However, the Gabès variety was characterized by a DMY significantly higher than the two other Lucernes, in the absence and presence of $\mathrm{NaCl}$. On the other hand, the Hunterfield and Hyb.555 varieties presented a marked sensibility to the salt. The severe decrease in the DMY of these two introduced varieties was especially related to the elimination of a party of the foliage by premature senescence, what was accelerated by the intensity and the duration of the salt stress, and also the result of the increasing of the difficulty to regenerate a new photosynthetical active leaves. According to Ghanem et al ., (2008) and Zhang et al., (2012), leaf senescence is one of the most limiting factors to tomato and cotton productivity respectively, under salinity. 
The sensibility to the salt of Hunterfield variety resulted from a bad dry matter repartition between roots, stems and leaves. Indeed, at the most stressful treatments, the leaves DM fraction was severely reduced by the salt. Besides, we noted in the leaves of this variety a necroses lesion what was accelerated their senescence. On the other hand, the native Gabès variety was characterized by a well-equilibrated distribution of the DM between the various organs.

In the presence of a moderate salt stress $\left(2.5 \mathrm{~g} . \mathrm{l}^{-1}\right)$, the LAR of the three alfalfa varieties increased. But, for the stressful treatments ( 5 and $10 \mathrm{~g} . \mathrm{l}^{-1}$ ), the LAR decreased significantly with the salt increasing in the culture medium for the three varieties; so Hunterfield has the LAR significantly lower. This was the result of the severe leaves sensibility to salt which was accelerated their senescence. On the contrary, the Gabès variety presented a low LAR decrease for the most stressful treatments; while Hyb555 occupied an intermediate position. In the three alfalfa varieties, the SLA was negatively affected by salt increasing. Decrease in alfalfa SLA under salt stress was attributed to the different sensitivity of leaf area expansion and photosynthesis. The sensibility of alfalfa leaves under salt stress resulted in an excessive accumulation of $\mathrm{Na}^{+}$and $\mathrm{Cl}^{-}$, entailing their premature senescence for the introduced varieties (data not shown). Our results confirm those of Rahimi et al., (2011) on the strawberry plants subjected to different $\mathrm{NaCl}$ concentrations.

The salt modified plant anatomical by increasing the leaves thickness. In our study, $\mathrm{NaCl}$ increased significantly the alfalfa leaf thickness at the stressful treatments. Our results confirmed those found by Longstreth and Nobel, (1979) working on three species represent a wide range of salinity tolerance, since bean (salt-sensitive), cotton (moderately tolerant), and Atriplex (halophyte), they found that the gradient salinities increased the leaf thickness due to the increase of palisade cells length and the number of spongy cell layers. The thickness of the leaf is related to the extension in the cell wall due to a higher turgor pressure on the cell wall. An increase in the number of spongy parenchyma and palisade parenchyma layers may also result in increased leaf thickness.

In salt stress, the succulence in dicotyledonous plants is an anatomical adaptive way to escape toxic ions $\mathrm{Na}^{+}$and $\mathrm{Cl}^{-}$by increasing in cell size due to the increases in vacuole volume. The three alfalfa varieties increased succulence with the rise of salt concentrations. The succulence permitted the accumulation of large amounts of water and dissolved $\mathrm{Na}^{+}$and $\mathrm{Cl}^{-}$ions in the leaves and preserved the physiological function like photosynthesis. In the three alfalfa varieties, the water content increased in concomitance with the increasing of the leaves succulence.

The water use efficiency (WUE), under salt stress decreased in the three alfalfa varieties. Indeed, the need of water supply to produce one gram of dry matter increased with increasing of salt concentration in the medium. However, compared to the introduced alfalfa varieties, Gabès variety has the WUE significantly higher in all of salt treatments. Hunterfield and Hyb.555 varieties had practically the same WUE. The decrease in WUE in the three varieties was attributed to the $\mathrm{CO}_{2}$ diffusion throw stomata to mesophyl cells. Indeed, Ashraf et al ., (2000) showed on wheat differing in salt tolerance, that WUE was more higher at the tolerant variety than on the sensitive one. For Chaves et al., (2009), WUE was function of the $\mathrm{CO}_{2}$ concentration in internal cells. In conclusion, this study allowed highlighting the interest of the Gabès variety in any selection program for salt tolerance.

\section{Acknowledgements}

This study was performed within the support of Ministry of Higher Education and Scientific Research through the financing of research work.

\section{References}

[1] Al Atiri R., 2004. Les efforts de modernisation de l'agriculture irriguée en Tunisie. Actes du Séminaire «Modernisation de l'Agriculture Irriguée». Rabat, du 19 au 23 avril 2004. 11p.

[2] Ben Nouna B., Zairi A., Ruelle P., Slatni A., Yacoubi S., Ajmi T., Oueslati T., 2004. Evaluation de la demande en eau et pilotage de l'irrigation déficitaire des cultures annuelles : méthodologie et outils de mesure. Actes du Séminaire «Modernisation de l'Agriculture Irriguée». Rabat, du 19 au 23 avril 2004.

[3] Boughalleb F., Hajlaoui H., Denden M., 2012. Effect of salt stress on growth, water relations, solute composition and photosynthetic capacity of the Xero-halophyte Nitraria retusa (L.). Environ. Res. J., 6(1): 1-13.

[4] Chaves M. M., Flexas J., Pinheiro C., 2009. Photosynthesis under drought and salt stress: regulation mechanisms from whole plant to cell. Annals of Botany, 103: 551-560.

[5] Da Silva E.C., Nogueira R.J.M.C., De Araújo F.P., De Melo N.F., De Azevedo Neto A.D.A., 2008. Physiological responses to salt stress in young umbu plants. Environ. and Exper. Botany, 63: 147-157

[6] Dahi S., 2008. «Le Lupin, aussi énergétique que le Soja, est cultivable dans toutes les terres de la Tunisie», Temps Economia : Sécurité alimentaire.

[7] Fercha A., Gherroucha H., Baka M., 2011. Improvement of salt tolerance in durum wheat by ascorbic acid application. J. of Stress Physiol. \& Bioch., 7(1): 27-37.

[8] Garnier E., Shipley B., Roumet C., Laurent G., 2001. A standardized protocol for the determination of specific leaf area and leaf dry matter content. Functional Ecology, 15: 688-695. 
[9] Ghanem M.E., Albacete A., Martínez-Andújar C., Acosta M., Romero-Aranda R., Dodd I.C., Lutts S., Perez-Alfocea F., 2008. Hormonal changes during salinity-induced leaf senescence in tomato (Solanum lycopersicum L.). J. Exper. Botany, 59(11): 30393050 .

[10] Hachicha M., 2007. Les sols salés et leur mise en valeur en Tunisie. Sécheresse, 18(1): 45-50.

[11] Hameed M., Ashraf M., Naz N., Al-Qurainy F., 2010. Anatomical adaptations of Cynodon dactylon (L.) Pers., from the salt range Pakistan, to salinity stress. I. Root and stem anatomy. Pak. J. Bot., 42(1): 279-289.

[12] Hammad S.A.R., Shaban Kh.A., Tantawy M.F., 2010. Studies on salinity tolerance of two peanut varieties in relation to growth, leaf water content, some chemical aspects and yield. J. of Applied Sci. Res., 6(10): 1517-1526.

[13] Hamrouni L., Hanana M., Abdelly C., Ghorbel A., 2011. Exclusion du chlorure et inclusion du sodium : deux mécanismes concomitants de tolérance à la salinité chez la vigne sauvage Vitis vinifera subsp. sylvestris (var. 'Séjnène $\square$ ). Biotechnol. Agron. Soc. Environ., 15(3), 387-400.

[14] Hanana M., Hamrouni L., Cagnac O., Eduardo Blumwald E., 2011. Mécanismes et stratégies cellulaires de tolérance à la salinité $(\mathrm{NaCl})$ chez les plantes. Dossiers environ., 19(NA): 121-140.

[15] Ibn Maaouia-Houimli S., Denden M., Dridi-Mouhandes B., Ben Mansour-Gueddes S., 2011. Caractéristiques de la croissance et de la production en fruits chez trois variétés de piment (Capsicum annuum L.) sous stress salin. Tropicultura, 29(2): 75-81.

[16] Javid M.G., Sorooshzadeh A., Moradi F., Modarres Sanavy S.A.M., Allahdadi I., 2011. The role of phytohormones in alleviating salt stress in crop plants. Australian J. of Crop Science, 5(6): 726-734.

[17] Lacerda C.F., Assis Júnior J.O., Filho L.C.A.L., De Oliveira T.S., Guimaràes F.V.A., Gomes-Flho E., Prisco J.T., Bezerra M.A., 2006. Morpho-physiological responses of cowpea leaves to salt stress. Braz. J. Plant Physiol., 18(4): 455-465.

[18] Li N., Chen S., Zhou X., Li C., Shao J., Wang R., Fritz E., Hüttermann A., Polle A., 2008. Effect of NaCl on photosynthesis, salt accumulation and ion compartmentation in two mangrove species, Kandelia candel and and Bruguiera gymnorhiza. Aquatic Botany, 88: 303-310.

[19] Longstreth, D.J. and P.S. Nobel, 1979. Salinity effects on leaf anatomy. Consequences for photosynthesis. Plant Physiol., 63: 700703.

[20] Lugan R., 2008. Phénotypage métabolique des réponses aux stress abiotiques chez Arabidopsis thaliana. Analyse fonctionnelle et intégrative du métabolome. Thèse de Doctorat de l'Université de Rennes $1.156 \mathrm{p}$.

[21] Marlet S., Bouksila F., Mekki I., Benaissa I., 2008. Fonctionnement et salinité de la nappe de l'oasis de Fatnassa : arguments géochimiques. In Kuper et Zaïri, (éd). Economies d'eau en systèmes irrigués au Maghreb. Actes du troisième atelier régional du projet Sirma, Nabeul, Tunisie, 4-7 juin 2007. Cirad, Montpellier, France, colloques-cédérom.

[22] Mezni M., Albouchi A., Bizid E., Hamza M., 2010. Minerals uptake, organic osmotica contents and water balance in alfalfa under salt stress. J. of Phytology, 2(11): 01-12.

[23] Mezni M., Bizid E., Harnza M., 1999. Effets de la salinité des eaux d'irrigation sur la survie et la croissance de trois variétés de luzerne pérenne. Fourrages, 158 : 169-178.

[24] Munns R. \& James R.A., 2003. Screening methods for salinity tolerance: a case study with tetraploid wheat. Plant and Soil, 253: 201-218.

[25] Munns R. and Tester M., 2008. Mechanisms of Salinity Tolerance. Annu. Rev. Plant Biol., 59: 651-81.

[26] Rahimi A., Biglarifard A., Mirdehghan H., Borghei S. F., 2011. Influence of NaCl salinity on growth analysis of strawberry cv. Camarosa. J. of Stress Physiol. \& Bioch., 7(4):145-156.

[27] Shahid M.A., Pervez M.A., Balal R.M., Ahmad R., Ayyub C.M., Abbas T., Akhtar N., 2011. Salt stress effects on some morphological and physiological characteristics of okra (Abelmoschus esculentus L.). Soil Environ. 30(1): 66-73.

[28] Singh P., Singh N., Sharma K.D. and Kuhad M.S., 2010. Plant Water Relations and Osmotic Adjustment in Brassica Species under Salinity Stress. J. of American Science, 6(6): 1-4.

[29] Smethurst C.F., Gill W.M., Shabala S., 2009. Using excised leaves to screen lucerne for salt tolerance: Physiological and cytological evidence. Plant Signaling \& Behavior, 4(1): 39-41.

[30] Suárez N. and Medina E., 2008. Salinity effects on leaf ion composition and salt secretion rate in Avicennia germinans (L.) L., Braz. J. Plant Physiol., 20(2):131-140.

[31] Suárez N., 2011. Comparative leaf anatomy and pressure-volume analysis in plants of Ipomoea pes-caprae experimenting saline and/ or drought stress. International J. of Botany, 7(1): 53-62.

[32] Sun J., Chen S-L., Dai S-X., Wang R-G., Li N-Y., Shen X., Zhou X-Y., Lu C-F., Zheng X-J., Hu Z-M., Zhang Z-K., Song J., Xu Y., 2009. Ion flux profiles and plant ion homeostasis control under salt stress. Plant Signal. Behav., 4(4): 261-264.

[33] Zhang H.J., Dong H.Z., Li W.J., Zhang D.M., 2012. Effects of soil salinity and plant density on yield and leaf senescence of fieldgrown cotton. J. Agronomy \& Crop Science, 198: 27-37. 